Marek Jaśkowski

\title{
Opinia Komisji w sprawie projektu rozporządzenia Parlamentu Europejskiego ustanawiającego przepisy i ogólne warunki regulujące wykonywanie funkcji Rzecznika Praw Obywatelskich (Statut Europejskiego Rzecznika Praw Obywatelskich) i uchylającego decyzję 94/262/EWWiS, WE, Euratom ${ }^{1}$
}

\author{
Opinion of the Commission on the draft regulation of the European \\ Parliament laying down the regulations and general conditions governing \\ the performance of the Ombudsman's duties (Statute of the European \\ Ombudsman) and repealing Decision 94/262/ECSC, EC, Euratom
}

\begin{abstract}
The European Commission has a mostly positive view of the draft EP regulation submitted by the European Parliament and states that many of the proposed changes consolidate current practice or introduce improvements. As regards some specific issues, the Commission made critical comments. Generally, the information of the Council of Ministers is in line with the opinion of the European Commission and deserves approval. The postulate contained in the information of the Council of Ministers to limit the scope of the concept of "maladministration" to violation of the right to good administration within the meaning of Art. 41 Charter of Fundamental Rights should be assessed negatively.
\end{abstract}

Keywords: European Commission, right to good administration, European Ombudsman, European Union

\footnotetext{
Komisja Europejska w znacznym stopniu pozytywnie ocenia przedłożony przez Parlament Europejski projekt jego rozporządzenia, stwierdzając, że wiele z proponowanych zmian utrwala obecną praktykę lub wprowadza ulepszenia. W odniesieniu do niektórych zagadnień Komisja zgłosiła uwagi krytyczne. Informacja Rady Ministrów jest zasadniczo zbieżna z opinią Komisji Europejskiej i zasługuje na aprobatę. Zawarty w informacji Rady Ministrów postulat ograniczenia zakresu pojęcia "niewłaściwego administrowania" do "naruszenia prawa do dobrej administracji" w rozumieniu art. 41 Karty praw podstawowych UE należy ocenić negatywnie.

Słowa kluczowe: Komisja Europejska, prawo do dobrej administracji, Europejski Rzecznik Praw Obywatelskich, Unia Europejska

doktor nauk prawnych, adiunkt .

Uniwersytet Kardynała Stefana Wyszyńskiego w Warszawie, Wydział Prawa i Administracji, Katedra Prawa Międzynarodowego i Europejskiego, WARSZAWA, POLSKA •

m.jaskowski@uksw.edu.pl • https://orcid.org/0000-0001-6598-810X
}

1 Opinia na temat opinii Komisji w sprawie projektu rozporządzenia Parlamentu Europejskiego ustanawiającego przepisy i ogólne warunki regulujące wykonywanie funkcji Rzecznika Praw Obywatelskich (Statut Europejskiego Rzecznika Praw Obywatelskich) i uchylającego decyzję 94/262/EWWiS, WE, Euratom sporządzona 2 stycznia 2020 r. na zlecenie przewodniczącego Komisji do Spraw Unii Europejskiej; BAS-WAPM-103/19. 


\section{Opinia merytoryczna}

\section{Przedmiot dokumentu UE}

\section{- Cel i treść dokumentu UE}

Przedmiotem opinii jest opinia Komisji Europejskiej (dalej: Komisja) w sprawie projektu rozporządzenia Parlamentu Europejskiego ustanawiającego przepisy i ogólne warunki regulujące wykonywanie funkcji Rzecznika Praw Obywatelskich (Statut Europejskiego Rzecznika Praw Obywatelskich) i uchylającego decyzję 94/262/EWWiS, WE, Euratom (dalej: opinia Komisji).

Opinia Komisji zawiera stanowisko tej instytucji w przedmiocie przedłożonego przez Parlament Europejski projektu Statutu Europejskiego Rzecznika Praw Obywatelskich (dalej: Statut) z 12 lutego 2019 r. Komisja w istotnym zakresie pozytywnie ocenia przedłożone przez Parlament Europejski rozwiązania, stwierdzając, że wiele z proponowanych zmian utrwala obecną praktykę lub wprowadza ulepszenia. Niemniej w odniesieniu do niektórych zagadnień Komisja zgłosiła uwagi krytyczne. Zakwestionowała w szczególności:

- treść motywu (5) projektu Statutu, dotyczącego kompetencji Europejskiego Rzecznika Praw Obywatelskich (dalej: ERPO) do wydawania zaleceń w przypadku stwierdzenia, że instytucja, organ lub jednostka organizacyjna Unii nie stosują prawidłowo orzeczenia sądu; w ocenie Komisji, zgodnie z Traktatem o funkcjonowaniu Unii Europejskiej (dalej: TfUE), ocena stosowania orzeczeń Trybunału Sprawiedliwości Unii Europejskiej (dalej: TSUE) jako taka wykracza poza mandat ERPO, podobnie jak dokonywanie interpretacji wyroków TSUE;

- przedłużenie terminu składania skargi do ERPO do 3 lat od daty stwierdzenia przez skarżącego stanu faktycznego, który miałby stanowić przedmiot skargi; zdaniem Komisji obecnie stosowany termin (2 lata) nie powodował żadnych problemów i nie ma odpowiedniego uzasadnienia przedłużenia tego okresu o rok; poza tym nadmierny upływ czasu może utrudnić organom administracji zajęcie się podniesioną kwestią;

- nowe przepisy dotyczące molestowania (mobbingu oraz molestowania seksualnego); według Komisji rozwiązywanie problemów z zakresu molestowania leży już w ramach ogólniej określonych kompetencji ERPO i nie ma potrzeby powierzania mu szczegółowej kompetencji w tych sprawach; poza tym przepisy dotyczące mobbingu/molestowania i jego skutków istnieją już w regulaminie pracowniczym; instytucje powinny też mieć możliwość oceny każdej sprawy, w tym sprawy dotyczącej molestowania seksualnego, i zajęcia się nią, zanim Rzecznik Praw Obywatelskich zbada, czy instytucje te zajęły się tą sprawą w odpowiedni sposób i czy doszło do niewłaściwego administrowania; z kolei niektóre z proponowanych przepisów nie wchodzą w zakres kompetencji ERPO (w szczególności ERPO nie jest organem odpowiedzialnym za stałą kontrolę lub nadzór konkretnych działań instytucji, ale działa na skutek 
wniesienia skargi; ponadto nie jest organem właściwym do udzielania porad personelowi UE);

- przyznanie ERPO kompetencji do przyjęcia przepisów wykonawczych do Statutu w zakresie, w jakim miałyby one dotyczyć zapewnienia ochrony urzędnikom lub innym pracownikom zgłaszającym przypadki molestowania seksualnego i naruszania prawa Unii bądź zgłaszania nieprawidłowości; ERPO nie posiada bowiem szczególnych uprawnień związanych z przypadkami molestowania seksualnego; poza tym regulamin pracowniczy nie wprowadza rozróżnienia między poszczególnymi rodzajami molestowania; w związku z tym pracownikom, którzy twierdzą, że dochodzi do jakiegokolwiek rodzaju molestowania, należy zapewnić takie same gwarancje jak pracownikom, którzy twierdzą, że dochodzi do molestowania seksualnego;

- przyznanie ERPO zadania polegającego na regularnym dokonywaniu oceny strategii i przeglądów obowiązujących procedur i w stosownych przypadkach formułowaniu konkretnych zaleceń; Komisja podkreśla, że ERPO nie jest organem odpowiedzialnym za stałą i regularną kontrolę lub nadzór nad określonymi działaniami innych instytucji, natomiast może zająć się tymi kwestiami w następstwie złożenia skargi;

- upoważnienie ERPO do udzielania poufnych porad personelowi UE w sprawach, w których następnie mogą być wszczynane przezeń dochodzenia; w ocenie Komisji może to prowadzić do konfliktu interesów i rzutować na obiektywność ERPO w takich sprawach; należy też skreślić odniesienie do zwolnienia $\mathrm{z}$ obowiązku zachowania tajemnicy służbowej; ponadto nie jest zgodne z traktatami odesłanie do art. 22a regulaminu pracowniczego;

- powierzenie ERPO dokonywania okresowego przeglądu procedur związanych z działaniami administracyjnymi instytucji, organów i jednostek organizacyjnych Unii oraz oceny, czy są one w stanie skutecznie zapobiegać konfliktom interesów, zagwarantować bezstronność i zapewniać pełne przestrzeganie prawa do dobrej administracji; w ocenie Komisji ERPO nie jest organem odpowiedzialnym za stałą kontrolę lub nadzór nad konkretnymi działaniami innych instytucji; może on zająć się tymi kwestiami na podstawie uprawnień do badania skarg lub wszczynania dochodzeń z inicjatywy własnej, ale tylko w kontekście ewentualnych przypadków niewłaściwego administrowania;

- wykluczenie z możliwości ubiegania się o stanowisko ERPO osób, które były członkami rządów krajowych lub instytucji unijnych w ciągu ostatnich 3 lat, a także uprzywilejowanie kandydatów na to stanowisko, którzy pełnili funkcję Rzecznika Praw Obywatelskich, w stosunku do kandydatów, którzy sprawowali krajowe urzędy sądowe.

Zdaniem Komisji należy poza tym doprecyzować przepisy dotyczące ujawniania ERPO informacji przez członków personelu UE. W szczególności Komisja uważa, że - zgodnie z art. 17 ust. 1 regulaminu pracowniczego - również w takim przypadku przed ujawnieniem informacji członkowie personelu muszą uzyskać 
zgodę swoich przełożonych. Co więcej, należy wyraźnie zaznaczyć, że członkowie personelu wypowiadają się w imieniu swojej jednostki organizacyjnej, a nie w imieniu własnym, ponieważ ERPO nie posiada uprawnień do indywidualnego ustalania faktów, nie może więc pod tym kątem przesłuchiwać świadków. Również przepisy dotyczące dostępu do dokumentów budzą w ocenie Komisji wątpliwości w świetle rozporządzenia 1049/2001. Komisja proponuje też modyfikację zaproponowanych przepisów dotyczących postępowania w tym zakresie.

\section{- Geneza dokumentu UE}

Artykuł 228 ust. 4 TfUE jest jednym z nielicznych przypadków, w których Parlament Europejski dysponuje inicjatywą ustawodawczą. Zgodnie z tym przepisem Parlament Europejski, stanowiąc w drodze rozporządzeń z własnej inicjatywy według specjalnej procedury ustawodawczej, po zasięgnięciu opinii Komisji i za zgodą Rady określa status i ogólne warunki pełnienia funkcji Rzecznika Praw Obywatelskich.

Statut ERPO jest obecnie określony na mocy decyzji 94/262 Parlamentu Europejskiego z dnia 9 marca 1994 r. w sprawie postanowień i ogólnych warunków wykonywania zadań przez Rzecznika Praw Obywatelskich ${ }^{2}$, wydanej na podstawie ówczesnego art. 195 ust. 4 Traktatu ustanawiającego Wspólnotę Europejską.

Projekt Statutu, zmierzający do uchylenia i zastąpienia decyzji 94/262, został uchwalony przez Parlament Europejski 12 lutego 2019 r. ${ }^{3}$ Parlament Europejski 25 marca 2019 r., zgodnie z art. 228 ust. 4 TfUE, skierował do Komisji Europejskiej pismo, w którym zwrócił się o opinię w sprawie projektu. Opinia (w skorygowanej wersji) została przedstawiona przez Komisję 18 listopada 2019 r.

\section{- Informacja o stanie prawa obowiązującego w Polsce w materii objętej treścią dokumentu UE}

Prawo polskie nie reguluje zagadnień stanowiących przedmiot dokumentu UE.

\section{Ocena dokumentu UE}

\section{- Ocena skutków dokumentu UE}

Opinia Komisji ma charakter niewiążący (art. 288 akapit 5 TfUE). Wynika z tego, że organ stanowiący może przyjąć akt mimo negatywnej treści opinii. Niemniej zawarte w opinii argumenty mogą zostać uwzględnione przez Radę, której zgoda jest konieczna do ostatecznego przyjęcia przepisów regulujących status ERPO.

Decyzja 94/262/EWWiS, WE, Euratom (Dz.Urz. UE L 113 z 04.05.1994, s. 15).

3 Rezolucja Parlamentu Europejskiego z dnia 12 lutego 2019 r. w sprawie projektu rozporządzenia Parlamentu Europejskiego ustanawiającego przepisy i ogólne warunki regulujące wykonywanie funkcji Rzecznika Praw Obywatelskich (Statut Europejskiego Rzecznika Praw Obywatelskich) i uchylającego decyzję 94/262/EWWiS, WE, Euratom (2018/2080(INL) - 2019/0900(APP)). 


\section{- Ocena zgodności działań UE, o których mowa w dokumencie UE, z zasadą pomocniczości}

Analizowana opinia Komisji nie podlega ocenie pod kątem zgodności z zasadą pomocniczości na podstawie protokołu $\mathrm{nr} 2 \mathrm{w}$ sprawie stosowania zasad pomocniczości i proporcjonalności, gdyż nie jest projektem aktu ustawodawczego UE.

\section{- Ustosunkowanie się do informacji Rady Ministrów}

Rada Ministrów (dalej: RM) zgadza się z opinią Komisji Europejskiej, że szereg zmian proponowanych w projekcie rozporządzenia utrwala obecną praktykę funkcjonowania Rzecznika lub wprowadza ulepszenia. Jednocześnie RM zasadniczo zgadza się z zarzutami podniesionymi przez Komisję w analizowanej opinii. W ocenie RM część proponowanych zmian wymaga zasadniczej modyfikacji, by przyjęcie rozporządzenia $\mathrm{w}$ proponowanym kształcie nie prowadziło do wprowadzenia rozwiązań wykraczających poza zakres kompetencji Rzecznika, określony w TfUE, i sprzecznych z innymi przepisami prawa UE (np. regulaminem pracowniczym) bądź z orzecznictwem TSUE.

W tym zakresie w informacji RM wskazano na istotne wątpliwości dotyczące projektu Statutu, które są przekonująco uargumentowane. W szczególności należy zgodzić się z poglądem, że TfUE przyznaje ERPO kompetencje do podejmowania działań $w$ konkretnych sprawach, natomiast nie przewiduje uprawnień o charakterze ogólnonadzorczym. Wynika to $\mathrm{z}$ art. 228 TfUE, który przewiduje, że ERPO jest uprawniony do przyjmowania od każdego obywatela Unii lub każdej osoby fizycznej bądź prawnej mającej miejsce zamieszkania lub statutową siedzibę w państwie członkowskim skarg, które dotyczą przypadków niewłaściwego administrowania. Również uprawnienie do podejmowania dochodzeń z własnej inicjatywy ERPO lub na wniosek członka Parlamentu Europejskiego przysługuje w kontekście konkretnej sprawy. Świadczy o tym treść art. 228 ust. 1 akapit 2 TfUE, który odnosi się do konkretnych faktów sprawy, jak również mówi o badaniu „przypadku niewłaściwego administrowania”.

Ponadto, w ocenie RM, aby móc efektywnie określić zakres kompetencji Rzecznika, zasadne jest zdefiniowanie pojęcia „niewłaściwego administrowania”. Rada Ministrów podkreśla, że „pojęcie to można definiować poprzez odniesienie do art. 41 Karty Praw Podstawowych, który dotyczy prawa do dobrej administracji. W konsekwencji niewłaściwe administrowanie oznaczałoby naruszenie prawa do dobrej administracji, czyli prawa do bezstronnego i sprawiedliwego rozpatrzenia sprawy w rozsądnym terminie, obejmującego (a) prawo do bycia wysłuchanym, (b) prawo dostępu do akt sprawy oraz (c) obowiązek uzasadnienia przez instytucję jej decyzji”.

W tym zakresie stanowisko RM należy ocenić negatywnie. Za niepożądane należy bowiem uznać ograniczenie pojęcia „niewłaściwego administrowania” do jedynie naruszenia art. 41 Karty praw podstawowych UE (dalej: KPP) w zakresie wskazanym przez RM. Przede wszystkim, mimo że art. 41 KPP mówi o „prawie do dobrej administracji", niemal sąsiadujący z nim art. 43 KPP przewiduje (po- 
dobnie jak art. 228 TfUE) możliwość wniesienia do ERPO skargi w przypadku „niewłaściwego administrowania” (a nie „naruszenia prawa do dobrej administracji”). W tej sytuacji nie należy utożsamiać obu pojęćc .

Dotychczas ERPO przyjmował, że „chociaż sprzeczność z prawem w kwestiach wchodzących w zakres kompetencji Rzecznika zawsze oznacza niewłaściwe administrowanie, niewłaściwe administrowanie nie jest automatycznie równoznaczne z naruszeniem prawa" ${ }^{5}$. Należy dodatkowo zwrócić uwagę, że w ramach analizy, czy doszło do przypadku niewłaściwego administrowania, ombudsman stosuje m.in. niewiążący Europejski kodeks dobrej praktyki administracyjnej ${ }^{6}$, który - obok zasad uznanych za wiążące zasady prawne - zawiera inne postanowienia. W świetle powyższych informacji można uznać, że w przedstawionym ujęciu „niewłaściwe administrowanie” obejmuje nie tylko przypadki naruszenia prawa, ale jest pojęciem szerszym ${ }^{7}$, wyrażony w informacji RM postulat ograniczenia jego zakresu jest zaś niepożądany z punktu widzenia ochrony indywidualnych interesów osób fizycznych i prawnych.

\section{Opinia prawna}

\section{Podstawa prawna przyjęcia dokumentu UE}

Opinia Komisji została wydana w toku specjalnej procedury ustawodawczej uregulowanej w art. 228 ust. 4 TfUE. Zgodnie z tym przepisem Parlament Europejski, stanowiąc w drodze rozporządzeń $\mathrm{z}$ własnej inicjatywy zgodnie ze specjalną procedurą ustawodawczą, po zasięgnięciu opinii Komisji i za zgodą Rady określa status i ogólne warunki pełnienia funkcji Rzecznika Praw Obywatelskich.

4 Zob. podobnie N. Diamandouros, The Relationship between the Principle of Good Administration and Legal Obligations [w:] Liber Amicorum en l'honneur de/in honour of Bo Vesterdorf, red. C. Baudenbacher, C. Gulmann, K. Lenaerts, E. Coulon, E. Barbier de la Serre, Bruxelles 2007, s. 340.

5 Europejski Rzecznik Praw Obywatelskich, Sprawozdanie roczne 2011, s. 15. Zob. również opinię rzecznik generalnej w sprawie C-331/05 P Internationaler Hilfsfonds: „[...] pod pojęciem niewłaściwego administrowania należy rozumieć co do zasady nie tylko naruszenie obowiązujących przepisów prawa, lecz także każde naruszenie zasad dobrej praktyki administracyjnej, które ze względu na ich niezobowiązujący charakter prawny można zakwalifikować jako tak zwane «soft law»" (pkt 68).

6 Uchwała Parlamentu Europejskiego z 6 września 2001 r.

7 Zob. szerzej M. Jaśkowski, Sądowa kontrola legalności aktów administracyjnych Unii Europejskiej, Warszawa 2016, s. 255 i n. Odmienne stanowisko zajęła Krystyna Kowalik-Bańczyk, której zdaniem „można też przyjąć, że Rzecznik stoi na straży «dobrej administracji», tak jak jest ona zdefiniowana w art. 41 KPP”. K. Kowalik-Bańczyk, Prawo do obrony w unijnych postępowaniach antymonopolowych w kierunku unifikacji standardów proceduralnych w Unii Europejskiej, Warszawa 2012. 


\section{Skutki prawne}

Opinia Komisji ma charakter niewiążący (art. 288 akapit 5 TfUE) w tym sensie, że organ stanowiący może przyjąć akt mimo negatywnej treści opinii. Niemniej należy podkreślić, że samo wydanie opinii przez Komisję stanowi niezbędny etap specjalnej procedury ustawodawczej, o której mowa w art. 228 ust. 4 TfUE, a jego pominięcie stanowiłoby naruszenie istotnego wymogu proceduralnego i skutkowałoby unieważnieniem wydanego w takich okolicznościach aktu prawnego (art. 263 akapit 2 w związku $\mathrm{z}$ art. 264 akapit 1 TfUE).

\section{Kwestie proceduralne}

- Procedura przyjmowania dokumentu UE

Przyjmowanie opinii nie jest związane z zachowaniem określonej, wynikającej z prawa traktatowego procedury. Omawiana opinia została przyjęta przez Komisję 18 listopada 2019 r. $^{8}$ i tego samego dnia przekazana do Sejmu.

\section{- Działania Komisji do Spraw Unii Europejskiej}

Komisja do Spraw Unii Europejskiej, działając w trybie z art. 3 ust. 2 ustawy z dnia 8 października 2010 r. o współpracy Rady Ministrów z Sejmem i Senatem w sprawach związanych z członkostwem Rzeczypospolitej Polskiej w Unii Europejskiej (Dz.U. nr 213, poz. 1395), wystąpiła do Rady Ministrów o przedstawienie informacji o sprawozdaniu. Informacja ta została przekazana przez Radę Ministrów 20 grudnia 2019 r. Komisja do Spraw Unii Europejskiej nie jest ograniczona terminami poza tymi, które mogą wynikać z celowości podejmowanych przez nią działań.

\section{Konkluzja}

Komisja Europejska w znacznym stopniu pozytywnie ocenia przedłożony przez Parlament Europejski projekt jego rozporządzenia ustanawiającego przepisy i ogólne warunki regulujące wykonywanie funkcji Rzecznika Praw Obywatelskich, stwierdzając, że wiele z proponowanych zmian utrwala obecną praktykę lub wprowadza ulepszenia. Niemniej w odniesieniu do niektórych zagadnień Komisja zgłosiła uwagi krytyczne.

Informacja RM jest zasadniczo zbieżna z opinią Komisji Europejskiej i zasługuje na aprobatę. Niemniej zawarty w informacji RM postulat ograniczenia zakresu pojęcia „niewłaściwego administrowania” należy ocenić negatywnie ze względów wskazanych w treści opinii.

8 Wersja opinii z 18 listopada zastępuje dwie wcześniejsze jej wersje, z 31 października i 4 listopada $2019 \mathrm{r}$. 


\section{Bibliografia}

Diamandouros N., The Relationship between the Principle of Good Administration and Legal Obligations [w:] Liber Amicorum en l'honneur de/in honour of Bo Vesterdorf, red. C. Baudenbacher, C. Gulmann, K. Lenaerts, E. Coulon, E. Barbier de la Serre, Bruxelles 2007.

Jaśkowski M., Sądowa kontrola legalności aktów administracyjnych Unii Europejskiej, Warszawa 2016.

Kowalik-Bańczyk K., Prawo do obrony w unijnych postępowaniach antymonopolowych w kierunku unifikacji standardów proceduralnych w Unii Europejskiej, Warszawa 2012. 